\title{
Nocardia salmonicida nom. rev., a fish pathogen
}

\author{
Kamil Isik, ${ }^{1}$ Jongsik Chun, ${ }^{2}$ Yung Chil Hah' ${ }^{2}$ and Michael Goodfellow ${ }^{1}$
}

\author{
Author for correspondence: Michael Goodfellow. Tel: +44 191222 7706. Fax: +44 1912225228. \\ e-mail:m.goodfellow@ncl.ac.uk
}

1 Department of
Agricultural and
Environmental Science,
University of Newcastle,
Newcastle upon Tyne
NE1 7RU, UK
2 Department of
Microbiology, College of
Natural Sciences and
Research Center for
Molecular Biology, Seoul
National University, Seoul
151-742, Republic of Korea

\begin{abstract}
An almost complete gene sequence of 165 rDNA of 'Nocardia salmonicida' strain JCM $4826^{\top}$ was determined following cloning and sequencing of the amplified gene. The sequence was aligned with those available for nocardiae and phylogenetic trees inferred using four tree-making algorithms. The organism and the type strain of Nocardia asteroides consistently formed a monophyletic clade with a distant sequence similarity of $97 \%$. However, previous DNA relatedness experiments showed that strain JCM $4826^{\top}$ and Nocardia asteroides ATCC $19247^{\top}$ belong to different genomic species. The organism was also distinguished from representatives of all validly described species of Nocardia using a combination of phenotypic features. The polyphasic evidence showed that the strain merits recognition as a new species of the genus Nocardia. The name proposed for the new species is Nocardia salmonicida nom. rev.
\end{abstract}

Keywords: Nocardia salmonicida nom. rev., polyphasic taxonomy, 16S rDNA sequencing

\section{INTRODUCTION}

The application of modern taxonomic methods promoted a radical reappraisal of the genus Nocardia (Trevisan, 1889; Goodfellow, 1997). The revised genus encompasses 13 validly described species which form a distinct monophyletic clade within the evolutionary radiation occupied by mycolic acid-containing actinomycetes, that is the mycolata (Chun \& Goodfellow, 1995; Chun et al., 1997, 1998; Friedman et al., 1998). The improved classification provides a sound framework for the recognition of additional species of Nocardia, including taxa which currently do not have any official standing in bacterial nomenclature.

Strain JCM $4826^{\mathrm{T}}$, a fish pathogen isolated from blueblack salmon (Oncorhynchus nerka), was assigned to the genus Streptomyces as Streptomyces salmonicida (Rucker, 1949) but was transferred to the genus Nocardia as Nocardia salmonicida when wholeorganism hydrolysates of the strain were found to contain meso-diaminopimelic acid, arabinose and galactose (Pridham \& Lyons, 1969; Pridham, 1970). This reclassification was subsequently underpinned by additional chemotaxonomic and morphological data (Goodfellow, 1971; Alderson et al., 1985; Kudo et al.,

The GenBank accession number for the 165 rDNA sequence of strain JCM $4826^{\top}$ is $Z 46750$.
1988) and the organism was shown to be most closely related to Nocardia asteroides on the basis of the results from DNA:DNA relatedness (Mordarski et al., 1977; Kudo et al., 1988) and numerical phenetic (Orchard \& Goodfellow, 1980) studies. 'Nocardia salmonicida' JCM $4826^{\mathrm{T}}$ also fell outwith the Streptomyces clusters in the numerical phenetic survey of Williams et al. (1983). The taxon was neither cited in the Approved Lists of Bacterial Names (Skerman et al., 1980) nor recognized in the current edition of Bergey's Manual of Systematic Bacteriology (Williams et al., 1989).

The aim of the present investigation was to clarify the relationships of 'Nocardia salmonicida' JCM $4826^{\mathrm{T}}$ using a polyphasic taxonomic approach. It was evident from the resultant genotypic and phenotypic data that the organism should be recognized as a new species of Nocardia for which the name Nocardia salmonicida nom. rev. is proposed.

\section{METHODS}

Bacterial strains. 'Nocardia salmonicida' JCM $4826^{\mathrm{T}}$ (= NRRL B-2778 ) was grown in shake flasks containing modified Sauton's broth (Mordarska et al., 1972) for $7 \mathrm{~d}$ at $30{ }^{\circ} \mathrm{C}$; biomass was harvested by centrifugation and washed twice with distilled water. Additional strains were examined in the phenotypic tests, namely Nocardia pseudobrasiliensis $\mathrm{N} 1237^{\mathrm{T}}$ (P. Boiron, Institut Pasteur, Paris; CIP 104600 ${ }^{\mathrm{T}}$ ), 
N1234 (P. Boiron; N249), N1235 (P. Boiron; N649) and N1236 (P. Boiron; N51511); Nocardia seriolae N1116 (JCM 3359), N1115 (JCM 3360), N1118 (JCM 5849) and N1119 (JCM 5850); and Nocardia transvalensis N1202 $\left(\mathrm{DSM} 43405^{\mathrm{T}}\right.$ ), N1213 (N. Poonwan, Department of Medical Sciences, Northaburi, Thailand; 35-157-10), N1214 (N. Poonwan; 34-104-03) and N1215 (N. Poonwan; 34-43-6). All of the strains were maintained as glycerol suspensions $(20 \%, \mathrm{v} / \mathrm{v})$ at $-20^{\circ} \mathrm{C}$.

Phenotypic characterization. The colonial properties of the test strains were determined on glucose yeast extract agar (GYEA; Gordon \& Mihm, 1962) plates after $14 \mathrm{~d}$ incubation at $30^{\circ} \mathrm{C}$. Smears from these plates were prepared, Gram-stained after Hucker's modification (Society for American Bacteriologists, 1957) and examined for micromorphological features. Smears were also stained using a modification of the Ziehl-Neelson method (Gordon, 1967) and the degree of acid-fastness noted. Unless otherwise stated, the remaining tests were read after incubation for $14 \mathrm{~d}$ at $30^{\circ} \mathrm{C}$. The degradation of adenine $(0 \cdot 4 \%)$, elastin $(0.3 \%)$, hypoxanthine $(0.4 \%)$, testosterone $(0.1 \%)$, Ltyrosine $(0.5 \%)$ and xanthine $(0.4 \%)$ were determined using GYEA as the basal medium with incubation for $21 \mathrm{~d}$ (Goodfellow, 1971). The degradation of uric acid was detected using nutrient agar as the basal medium (Boiron et al., 1993); zones of clearing around colonies were scored as positive after incubation for $21 \mathrm{~d}$. Established procedures were used to detect aesculin hydrolysis (Williams et al., 1983), nitrate reduction (Gordon \& Mihm, 1962) and urea hydrolysis (Rustigan \& Stuart, 1941). The ability of the strains to grow on carbon compounds (Table 1) as sole sources of carbon for energy and growth was examined using Stevenson's basal medium (Stevenson, 1967). Growth at $45^{\circ} \mathrm{C}$ was recorded on GYEA plates.

165 rDNA sequencing. Isolation of chromosomal DNA, and PCR, cloning and sequencing of the 16S rDNA of strain JCM $4826^{\mathrm{T}}$ were carried out using a Taq DyeDeoxy Terminator Cycle Sequencing Kit and a 373A DNA Sequencer (Applied Biosystems) as described previously (Chun \& Goodfellow, 1995). The resultant 16S rDNA sequence was aligned manually against sequences of representative mycolata strains; the additional sequence data were retrieved from the GenBank and EMBL databases. Phylogenetic trees were inferred using the Fitch-Margoliash (Fitch \& Margoliash, 1967), maximum-likelihood (Felsenstein, 1981), maximum-parsimony (Fitch, 1972) and neighbour-joining (Saitou \& Nei, 1987) treeing algorithms. Evolutionary distance matrices for the neighbour-joining and Fitch-Margoliash methods were generated according to Jukes \& Cantor (1969). The PHYLIP package (Felsenstein, 1993) was used for all the analyses. The resultant unrooted tree topologies were evaluated in bootstrap analyses (Felsenstein, 1985) of the neighbour-joining method based on 1000 resamplings.

Chemotaxonomy. Freeze-dried biomass of strain JCM $4826^{\mathrm{T}}$ $(50 \mathrm{mg})$ was degraded by acid methanolysis and hexane extracts examined for mycolic acids by TLC as described by Minnikin et al. $(1975,1980)$. Menaquinone was analysed using HPLC as described previously (Chun \& Goodfellow, 1995).

\section{RESULTS AND DISCUSSION}

An almost complete $16 \mathrm{~S}$ rDNA sequence (1471 nt) was obtained for strain JCM $4826^{\mathrm{T}}$. Comparison of this sequence with corresponding nucleotide sequences of representative actinomycetes showed that the organism belongs to the genus Nocardia (data not shown). This result confirms and extends data from previous studies which indicated that strain JCM $4826^{\mathrm{T}}$ has morphological and chemotaxonomic properties consistent with its assignment to the genus Nocardia (Pridham \& Lyons, 1969; Orchard \& Goodfellow, 1980; Alderson et al., 1985; Kudo et al., 1988). It was also shown that strain JCM $4826^{\mathrm{T}}$ contains mycolic acids with an $R_{\mathrm{F}}$ value on TLC plates within the range typical of nocardiae. In addition, the strain contained predominant amounts of hexahydrogenated menaquinones with eight isoprene units where the end two units were cyclized; this menaquinone profile has been found only in members of the genera Nocardia and Skermania (Chun \& Goodfellow, 1995; Chun et al., 1997).

The unrooted evolutionary tree (Fig. 1) shows that strain JCM $4826^{\mathrm{T}}$ forms a monophyletic clade with Nocardia asteroides. This relationship was highlighted in the analyses based on all four treeing algorithms by the relatively high nucleotide similarity value $(97 \%)$ and the high bootstrap value $(76 \%)$ based on the neighbour-joining method. This relationship between 'Nocardia salmonicida' JCM $4826^{\mathrm{T}}$ and Nocardia asteroides strains, including the type strain, is also supported by DNA-DNA relatedness studies (Mordarski et al., 1977; Kudo et al., 1988) where the relatedness values between the two strains ranged from 45 to $57 \%$. However, it is apparent from these studies that strain JCM $4826^{\mathrm{T}}$ forms a distinct genomic species within the genus Nocardia. It is also clear from both the present and earlier studies that strain JCM $4826^{\mathrm{T}}$ can be distinguished from representatives of all of the validly described species of Nocardia, including Nocardia asteroides, using a battery of phenotypic properties (Table 1).

The genotypic and phenotypic data indicate that strain JCM $4826^{T}$ merits recognition as a distinct species in the genus Nocardia. It is therefore proposed that the organism be classified in the genus Nocardia as Nocardia salmonicida nom. rev.

\section{Description of Nocardia salmonicida nom. rev.}

Nocardia salmonicida (sal.mo.ni'ci.da. L. n. salmo, salmonis salmon; L. suff. cida from L. v. caedo to cut or kill; M.L. n. salmonicida salmon-killer).

The description is based on data taken from this and previous studies (Rucker, 1949; Shirling \& Gottlieb, 1972; Orchard \& Goodfellow, 1980; Kudo et al., 1988). Aerobic, Gram-positive, catalase-positive, partially acid-alcohol-fast, non-motile actinomycete which produces an extensively branched substrate mycelium which fragments in situ into rod-shaped to coccoid elements. An orange substrate mycelium carries white to pink aerial hyphae. Colony elevation is convex to irregular and colony margins are filamentous. Diffusible pigments are not formed. Tes- 


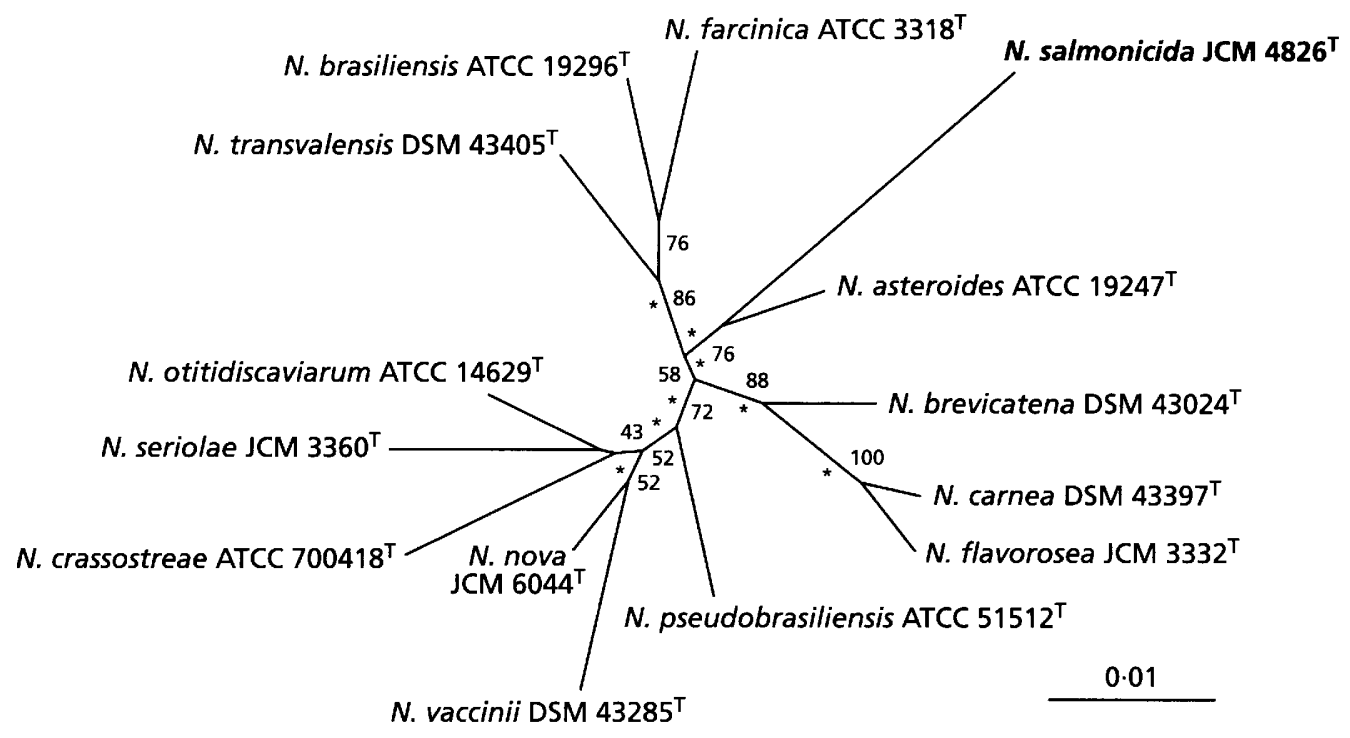

Fig. 1. Unrooted neighbour-joining tree based on 1407 unambiguously aligned nucleotide positions. Asterisks indicate the branches that were also recovered using the Fitch-Margoliash, maximum-likelihood and maximum-parsimony methods. The numbers at the nodes indicate the levels of bootstrap support based on neighbour-joining analyses of 1000 resampled data sets. The scale represents $0.01 \mathrm{nt}$ substitutions per position.

Table 1. Phenotypic characters which distinguish strain JCM $4826^{\top}$ from other nocardiae

Data taken from this study and from Orchard \& Goodfellow (1980), Goodfellow (1997), Chun et al. (1998) and Friedman et al. (1998).,$+>90 \%$ of strains positive;,$->90 \%$ of strains negative; ND, not determined.

\begin{tabular}{|c|c|c|c|c|c|c|c|c|c|c|c|c|c|c|}
\hline Character & $\begin{array}{l}\text { JCM } \\
\mathbf{4 8 2 6}^{\mathrm{T}} a\end{array}$ & $\begin{array}{l}N . \\
\text { asteroides }\end{array}$ & $\begin{array}{c}N . \\
\text { brasiliensis }\end{array}$ & $\begin{array}{c}N . \\
\text { brevicatena } \\
\text { DSM 43024 }^{\mathrm{T}}\end{array}$ & $\begin{array}{c}N . \\
\text { carnea }\end{array}$ & $\begin{array}{c}N . \\
\text { crassostreae }\end{array}$ & $\begin{array}{c}N . \\
\text { farcinica }\end{array}$ & $\begin{array}{c}N . \\
\text { flavorosea }\end{array}$ & $\begin{array}{c}N . \\
\text { nova }\end{array}$ & $\begin{array}{c}N . \\
\text { otitidiscaviarum }\end{array}$ & $\begin{array}{c}N . \\
\text { pseudobrasiliensis }\end{array}$ & $\begin{array}{c}N . \\
\text { seriolae }\end{array}$ & $\begin{array}{c}N . \\
\text { transvalensis }\end{array}$ & $\begin{array}{c}\text { N. vaccinii } \\
\text { DSM 43285 }\end{array}$ \\
\hline \multicolumn{15}{|l|}{ Biochemical tests } \\
\hline Aesculin hydrolysis & + & + & + & + & + & + & + & - & + & + & + & + & + & + \\
\hline Nitrate reductase & + & + & + & - & + & ND & + & - & + & + & - & - & + & + \\
\hline Urea hydrolysis & + & + & + & - & - & - & + & - & + & + & + & - & + & + \\
\hline \multicolumn{15}{|l|}{ Decomposition of: } \\
\hline Hypoxanthine & - & - & + & - & .. & - & - & - & - & + & + & - & + & \\
\hline Testosterone & + & + & + & + & + & $\mathrm{ND}$ & + & + & + & - & - & - & + & - \\
\hline Tyrosine & + & - & + & - & - & - & - & - & - & - & + & - & - & - \\
\hline Uric acid & - & - & - & ND & - & ND & - & - & - & + & + & - & + & - \\
\hline Xanthine & - & - & - & - & - & - & - & - & - & + & - & - & - & - \\
\hline \multicolumn{15}{|c|}{ Growth on sole carbon sources } \\
\hline $\begin{array}{l}\mathrm{D}(+) \text {-Mannitol } \\
(1 \%)\end{array}$ & + & - & + & - & + & ND & - & + & - & + & + & - & + & + \\
\hline Growth at $45^{\circ} \mathrm{C}$ & - & - & + & - & - & - & + & - & - & + & - & - & - & - \\
\hline
\end{tabular}

tosterone, L-tyrosine and Tweens 20 and 80 are degraded, but not adenine, casein, cellulose, chitin, elastin, guanine, hypoxanthine, starch, xanthine or xylan. Nitrate is reduced and aesculin and urea hydrolysed. Acid is formed from $\mathrm{D}(+)$-glucose and glycerol but not from $\mathrm{L}(-)$-arabinose, meso-erythritol, $\mathrm{D}(+)$-galactose, $\mathrm{D}(+)$-maltose, $\mathrm{D}(+)$-mannose, $\alpha$-L- rhamnose or $\mathrm{D}(+)$-trehalose. $\mathrm{D}(-)$-Fructose, $\mathrm{D}(+)$ glucose, $\mathrm{D}(+)$-mannitol, $\mathrm{D}(+)$-sorbitol, butyrate, citrate, fumarate, malate, propionate and succinate are used as sole carbon sources for energy and growth but not amygdalin, $\mathrm{D}(-)$ - or $\mathrm{L}(-)$-arabinose, arbutin, $\mathrm{D}(+)$-cellobiose, dulcitol, $\mathrm{D}(+)$-galactose, glycogen, meso-inositol, inulin, $\mathrm{D}(+)$-melezitose, $\mathrm{D}(+)$ - 
raffinose, $\alpha$-L-rhamnose, acetamide, acetate, anthranilic acid, benzoate, 1,4-butanediol, 2,3-butanediol, hippurate, 4-hydroxybenzoate, lactate, malonate, 2octanol, pimelic acid or tartrate. Acetamide, Lcysteine, L-glutamate, L-serine, sodium nitrate, $\left(\mathrm{NH}_{4}\right)_{2} \mathrm{HPO}_{4}$, pyrazinamide, L-serine and urea are used as sole nitrogen sources but not L-phenylalanine. Neither monoethanolamine nor trimethylenediamine are used as sole sources of carbon and nitrogen. Growth occurs between 20 and $30^{\circ} \mathrm{C}$ and in the presence of bismuth citrate $(0.0001 \%)$, crystal violet $(0.00001 \%)$, phenol $(0.01 \%)$, sodium chloride $(3 \%$, $\mathrm{w} / \mathrm{v}$ ) and lysozyme but not at 10 or $35^{\circ} \mathrm{C}$, nor in the presence of sodium azide $(0.01 \%)$ or sodium chloride $(10 \%, \mathrm{w} / \mathrm{v})$. The major cellular fatty acids are hexadecanoic ( $32 \%$ of total fatty acids), hexadecenoic $(14 \%)$, octadecenoic $(16 \%)$ and 10-methyloctadecenoic $(25 \%)$ acids. The $\mathrm{G}+\mathrm{C}$ ratio of the DNA is $67 \mathrm{~mol} \%$. The organism is pathogenic for cultured fish. The type strain is JCM $4826^{\mathrm{T}}$ (= ATCC $27463^{\mathrm{T}}$ $=\mathrm{CBS} 694.72^{\mathrm{T}}=\mathrm{IFO} 13393^{\mathrm{T}}=\mathrm{ISP} 5472^{\mathrm{T}}=\mathrm{NRRL}$ $\mathrm{B}-2778^{\mathrm{T}}$ ). The species description is based on a single strain and hence serves as the type strain description.

\section{ACKNOWLEDGEMENTS}

Part of this work was supported through the UK-Korea Actinomycete Research Programme (BBSRC grant R185/ $05688 / 01)$, the British Council Academic Link Scheme (Seoul, Korea) and by a Korean Science and Engineering Council (KOSEF) grant to the Research Center for Molecular Microbiology. Kamil Isik was supported by a scholarship from Ondokuz Mayis University, Samsun and the Government of Turkey. The authors are indebted to colleagues for providing cultures.

\section{REFERENCES}

Alderson, G., Goodfellow, M. \& Minnikin, D. E. (1985). Menaquinone composition in the classification of Streptomyces and other sporoactinomycetes. J Gen Microbiol 131, 1671-1679.

Boiron, P., Provost, F. \& Duport, B. (1993). Laboratory Methods for the Diagnosis of Nocardiosis. Paris: Institut Pasteur.

Chun, J. \& Goodfellow, M. (1995). A phylogenetic analysis of the genus Nocardia with $16 \mathrm{~S}$ rRNA gene sequences. Int $J$ Syst Bacteriol 45, 240-245.

Chun, J., Blackall, L., Kang, S.-O., Hah, Y. C. \& Goodfellow, M. (1997). A proposal to reclassify Nocardia pinensis Blackall et al. as Skermania piniformis gen. nov., comb. nov. Int $J$ Syst Bacteriol 47, 127-131.

Chun, J., Seung, C.-N., Bae, K.-S., Lee, K.-J., Kang, S.-O., Goodfellow, M. \& Hah, Y. C. (1998). Nocardia flavorosea sp. nov. Int J Syst Bacteriol 48, 901-905.

Felsenstein, J. (1981). Evolutionary trees from DNA sequences: a maximum likelihood approach. $J$ Mol Evol 17, 368-376.

Felsenstein, J. (1985). Confidence limits on phylogenies: an approach using the bootstrap. Evolution 39, 783-791.

Felsenstein, J. (1993). PHYLIP (Phylogeny Inference Package) version 3.5c. Seattle: Department of Genetics, University of Washington.

Fitch, W. M. (1972). Towards defining the course of evolution: minimum change for a specific tree topology. Syst Zool 20, 406-416.

Fitch, W. M. \& Margoliash, E. (1967). Construction of phylogenetic trees: a method based on mutation distances as estimated from cytochrome $c$ sequences is of general applicability. Science 155, 279-284.

Friedman, C. S., Beaman, B. L., Chun, J., Goodfellow, M., Gee, A. \& Hedrick, R. P. (1998). Nocardia crassostreae sp. nov., the causal agent of nocardiosis in Pacific oysters. Int $J$ Syst Bacteriol 48, 237-246.

Goodfellow, M. (1971). Numerical taxonomy of some nocardioform bacteria. J Gen Microbiol 69, 33-80.

Goodfellow, M. (1997). Nocardia and related genera. In Topley and Wilson's Microbiology and Microbial Infections, 9th edn, vol. 2, Systematic Bacteriology, pp. 463-489. Edited by A. Balows \& B. I. Duerden. London: Arnold.

Gordon, R. E. (1967). The taxonomy of soil bacteria. In The Ecology of Soil Bacteria, pp. 293-321. Edited by T. R. G. Gray \& D. Parkinson. Liverpool: Liverpool University Press.

Gordon, R. E. \& Mihm, J. M. (1962). Identification of Nocardia caviae (Erikson) nov. comb. Ann N Y Acad Sci 98, 628-636.

Jukes, T. H. \& Cantor, C. R. (1969). Evolution of protein molecules. In Mammalian Protein Metabolism, pp. 21-132. Edited by H. N. Munro. New York: Academic Press.

Kudo, T., Hatai, K. \& Seino, A. (1988). Nocardia seriolae sp. nov. causing nocardiosis of cultured fish. Int $J$ Syst Bacteriol 38, 173-178.

Minnikin, D. E., Alshamaony, L. \& Goodfellow, M. (1975). Differentiation of Mycobacterium, Nocardia and related taxa by thin-layer chromatographic analyses of whole-cell methanolysates. J Gen Microbiol 88, 200-204.

Minnikin, D. E., Hutchinson, I. G., Caldicott, A. B. \& Goodfellow, M. (1980). Thin-layer chromatography of methanolysates of mycolic acid-containing bacteria. J Chromatogr 188, 221-223.

Mordarska, H., Mordarski, M. \& Goodfellow, M. (1972). Chemotaxonomic characters and classification of some nocardioform bacteria. $J$ Gen Microbiol 71, 77-86.

Mordarski, M., Goodfellow, M., Szyba, K., Pulverer, G. \& Tkacz, A. (1977). Classification of the 'rhodochrous' complex and allied taxa based on deoxyribonucleic acid reassociation. Int J Syst Bacteriol 27, 31-37.

Orchard, V. A. \& Goodfellow, M. (1980). Numerical classification of some named strains of Nocardia asteroides and related isolates from soil. J Gen Microbiol 118, 295-312.

Pridham, T. G. (1970). New names and new combinations in the order Actinomycetales Buchanan 1917. US Dep Agric Tech Bull 1424, 1-55

Pridham, T. G. \& Lyons, A. J., Jr (1969). Progress in clarification of the taxonomic and nomenclatural status of some problem actinomycetes. Dev Ind Microbiol 10, 183-221.

Rucker, R. R. (1949). A streptomycete pathogenic to fish. $J$ Bacteriol 58, 659-664.

Rustigan, R. \& Stuart, C. A. (1941). Decomposition of urea by Proteus. Proc Soc Exp Biol Med 47, 108-112.

Saitou, N. \& Nei, M. (1987). The neighbor-joining method: a new method for reconstructing phylogenetic trees. Mol Biol Evol 4, 406-425.

Shirling, E. B. \& Gottlieb, D. (1972). Cooperative description of type strains of Streptomyces. V. Additional descriptions. Int $J$ Syst Bacteriol 22, 265-394.

Skerman, V. B. D., McGowan, V. \& Sneath, P. H. A. (1980). 
Approved lists of bacterial names. Int $J$ Syst Bacteriol 30, $225-420$

Society for American Bacteriologists (1957). Manual of Microbiological Methods. New York: McGraw-Hill.

Stevenson, J. L. (1967). Utilization of aromatic hydrocarbons by Arthrobacter spp. Can J Microbiol 13, 205-211.

Trevisan, V. (1889). I Generi e la Specie dell Batteriacee. Milan: Zanaboni \& Gabuzzi.
Williams, S. T., Goodfellow, M., Alderson, G., Wellington, E. M. H., Sneath, P. H. A. \& Sackin, M. J. (1983). Numerical classification of Streptomyces and related genera. J Gen Microbiol 129, 1743-1813.

Williams, S. T., Goodfellow, M. \& Alderson, G. (1989). Genus Streptomyces Waksman and Henrici, 1943, 339 AL. In Bergey's Manual of Systematic Bacteriology, vol. 4, pp. 2452-2492. Edited by S. T. Williams, M. E. Sharpe \& J. G. Holt. Baltimore: Williams \& Wilkins. 